\title{
Reliability of adenoid hypertrophy diagnosis by cephalometric radiography
}

\author{
Confiabilidade do diagnóstico da hipertrofia das adenóides por meio da cefalometria
}

Alexandre Jose RETCHESKI ${ }^{1}$

Nelson Padilha da SILVA ${ }^{1}$

Fernanda LEITE ${ }^{1}$

Paulo Roberto Aranha NOUER ${ }^{1}$

\section{ABSTRACT}

\section{Objective}

To verify the reliability of adenoid hypertrophy diagnosis by cephalometric radiography.

\begin{abstract}
Method
Thirty male subjects, aged between 12 and 15 years, either mouth-breathers, or not, were selected. Diagnostic tests for adenoid hypertrophy were performed by radiological cephalometry based on lateral cephalometric radiographs and nasal endoscopy (gold standard). The CefX Cephalometric software program, version 2000 was used and the rhinoscopy was performed with a flexible endoscope. Blockage of $47 \%$ and $75 \%$ of the nasopharynx were taken as the cutoff points for cephalometric radiography and endoscopy, respectively.
\end{abstract}

\section{Results}

The correlation between the two examinations was considered moderately positive (0.5). Tests of validity and reliability reported a sensitivity of $100 \%$; specificity $65.5 \%$; positive predictive value of $9.1 \%$; negative predictive value $100 \%$, and exactness of $66.60 \%$.

\section{Conclusion}

Lateral cephalometric radiography was considered practical and comfortable for the patient; relatively efficient for detecting adenoid hypertrophy and obtaining the diagnosis of nasopharyngeal airway obstruction.

Indexing terms: Adenoids. Cephalometrics. Hypertrophy. Mouth breathing.

\section{RESUMO}

\section{Objetivo}

Verificar a confiabilidade do diagnóstico da hipertrofia das adenóides por meio da cefalometria.

\section{Métodos}

Trinta indivíduos do gênero masculino, com idades entre 12 e 15 anos, respiradores bucais ou não, foram selecionados e neles realizados exames de diagnóstico de hipertrofia da adenóide por cefalometria radiológica, a partir da telerradiografia em norma lateral e exames rinoscópicos, a partir da nasofibroscopia (padrão ouro). A cefalometria utilizada foi a computadorizada e para isto se utilizou o programa CefX versão 2000 e a rinoscopia foi realizada com um nasofibroscópio flexível. Foi tomado como ponto de corte $47 \%$ e $75 \%$ de bloqueio da nasofaringe para a telerradiografia e nasofibroscopia, respectivamente.

\section{Resultados}

A correlação encontrada entre os dois exames foi considerada moderadamente positiva $(0,5)$ e os testes de validade e confiabilidade registraram uma sensibilidade de $100 \%$, especificidade de $65,5 \%$, valor preditivo positivo de $9,1 \%$, valor preditivo negativo de $100 \%$ e exatidão de $66,60 \%$.

\section{Conclusão}

A telerradiografia lateral foi considerada um meio prático, confortável para o paciente e relativamente eficiente na detecção da hiperplasia da adenóide e na obtenção do diagnóstico de obstrução nasofaringeana.

Termos de indexação: Tonsila faríngea. Circunferência craniana. Hipertrofia. Respiração bucal.

\section{INTRODUCTION}

In spite of the lack of consensus about the causes and exact effects of chronic nasal obstructions, their diagnosis is fundamental for performing orthodontic treatment and ensuring its stability. Oliveira et al. ${ }^{1}$, consider that obstructions mainly occur by the increase in volume of the adenoids.

\footnotetext{
${ }^{1}$ Faculdade São Leopoldo Mandic, Curso de Odontologia, Programa de Pós-Graduação em Ortodontia. Rua José Rocha Junqueira, 13, Swift, 13045755, Campinas, SP, Brasil. Correspondência para / Correspondence to: PRA NOUER. E-mail: <nouerp3@gmail.com>
} 
There are various examination options for diagnosis of this hypertrophy, and these may include: computed tomography, magnetic resonance; computed rhinomanometry and acoustic rhinometry ${ }^{1}$. However, the method most used for diagnosis of obstruction or chronic inflammation of the nasopharyngeal space is by means of radiography of the cavum and lateral teleradiography ${ }^{2}$ by means of cephalometry. This resource has been included in the admission protocol of the orthodontic patient.

While nasofibroscopy, an exam that allows visual and direct observation of the region is an excellent diagnostic exam, it is a more complex exam to obtain when compared with diagnosis by lateral telegradiography.

The adenoids are formed $b$ a collection of lymphoid nodules situated in the posterior wall and roof of the nasopharynx. Hypertrophy of these tissues may occur in healthy children, or result from infections that determine obstruction of the nasopharynx, and there may be clinical manifestations such as snoring and sleep apnea.

Holmberg \& Linder-Aronson ${ }^{3}$ conducted a research with the purpose of quantifying the capacity of the nasal and nasopharyngeal air spaces, in lateral and frontal radiographs. The samples consisted of 162 children, of whom cephalograms were taken and rhinoscopies performed. The results indicated a close relationship between the size of the adenoid, measured in lateral radiographs, and clinical access. Furthermore, an inverse relationship was shown between the size of the adenoid and airflow. Finally, the authors concluded that the lateral radiograph is a satisfactory tool for the measurement of the adenoid and airways.

Cohen et al. ${ }^{4}$ published a study correlating the radiograph of the cavum and size of the adenoid, and concluded that the radiological study would be an adequate exam in pre-operative evaluation of the child indicated for adenoidectomy, but recognized the inherent limitations of this exam, finding a weak correlation between the radiograph and the operative observations (Pearson's coefficient: 0.34).

Wang et al. ${ }^{5}$ were able to correlate the existence of adenoid hypertrophy with the lateral radiograph of the cavum in $88 \%$ of the cases, when submitted to nasal endoscopy. However, in $26 \%$ of the cases, the radiological exam failed to confirm the adenoidal tissue hypertrophy, when compared with endoscopy.

Gianni Filo et al. ${ }^{6}$ selected 30 patients ranging from seven to 12 years and submitted them to having teleradiographs taken and nasopharyngeal endoscopies performed with the purpose of comparing obstruction of the nasopharyngeal air space. Taking rhinoscopy as the gold standard, the radiographic exam showed a sensitivity of $0.88 \%$ and a specificity of $0.40 \%$ for the diagnosis of hypertrophy of the inferior turbinate. Whereas, for diagnosis of hypertrophy of the middle turbinate, the results found were $1.00 \%$ and $0.20 \%$ for sensitivity and specificity, respectively. They concluded that video nasopharyngeal endoscopy was shown to be more convenient for diagnosing the diverse nasopharyngeal obstructive processes than lateral cephalometric teleradiography.

Barbosa et al. ${ }^{7}$ published a study with 30 individuals (7 to 12 years old) in whom nasal endoscopy and lateral cephalometric exams were performed. They considered patients as presenting severe adenoid hypertrophy, when their endoscopy showed nasopharyngeal obstruction equal to or higher than $75 \%$, and in radiographs, the smallest anteroposterior diameter of the nasopharynx equal to or smaller than $5 \mathrm{~mm}$. The radiographic exam showed a sensitivity of $75 \%$ and specificity of $86.3 \%$. These results led them to conclude that the lateral cephalometric radiograph would be an efficient exam for the diagnosis of adenoid hypertrophy.

In this study, the endeavor was to evaluate the degree of reliability of the diagnoses of adenoid hypertrophy with the use of cephalometry.

\section{METHODS}

The sample consisted of patients from the public health service, Health Center NIS III, in the city of Guarapuava (PR), Brazil All patients were informed the details of the research, and signed the term of free and informed consent, in accordance with the regulations protocolled by the Research Ethics Committee of the São Leopoldo Mandic Dental School, Protocol No. 2006/0361.

Thirty individuals of the male gender, in the agerange between 12 and 15 years were selected, whether they were mouth-breathers or not, and who had not been submitted to orthodontic treatment, tonsil or adenoid surgeries. Also included were those patients who, in the anamnesis presented allergy problems, clinically found by the association of two or more of the following symptoms: sneezing, abundant, clear nasal discharge, nasal obstruction, and intense nasal itching and/or of the palate and eyes, with itching also occurring in the external auditory canal and pharynx. 
All had lateral teleradiographs taken, by the one and the same technician, who used the Gendex apparatus, Kodak Lamex regular $18 \times 24 \mathrm{~cm}$ film with automatic development. The method of obtaining these radiographs was in compliance with the natural position of the head, according to Moorrees \& Kean ${ }^{8}$ and Rocabado?.

The computed cephalometry software program CefX 2000 was used, with the measurements taken by one single operator, in order not to obtain any information from the patient. Starting from the following points: Sella, Basion, superior-anterior airway, inferior-anterior airway, Point AD1 and Point AD2, the program calculated the percentage of space occupied by the adenoids (Figure 1). Seven days later, $20 \%$ of the sample were selected by draw for a new cephalometric test with the purpose of evaluating the error.

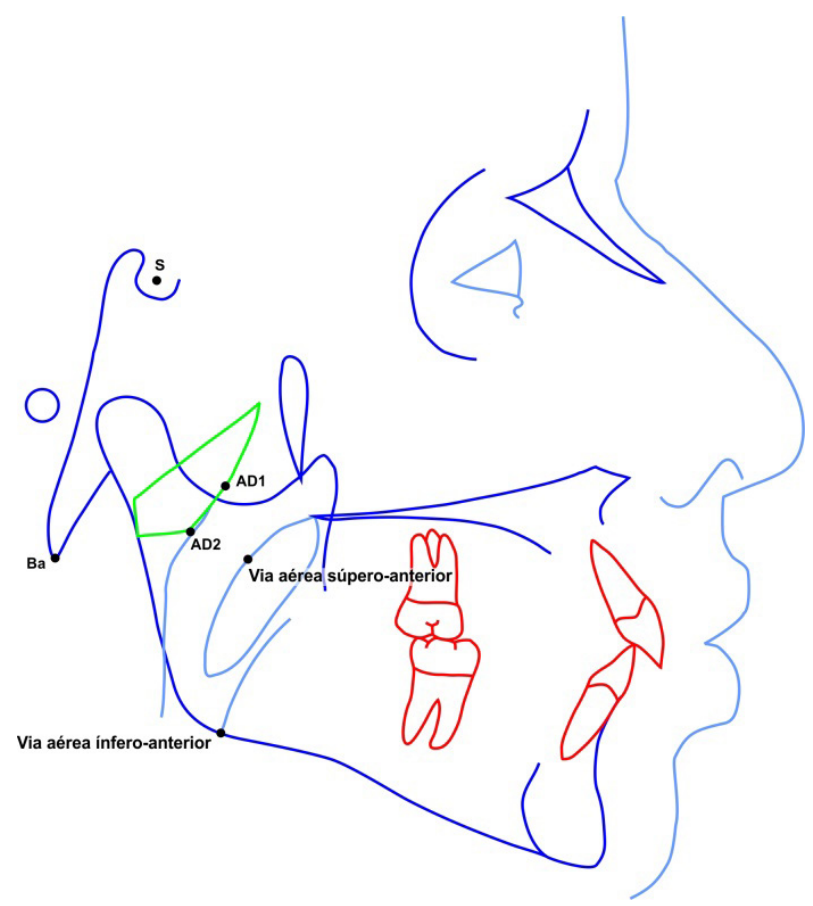

Figure 1. Drawing of the adenoids in green color, made by tracing. Source: Software Program CefX 2000.

All the nasofibroscopies were saved on VHS tape and the interpretations provided in the report were made in an independent manner, without correlation with the data of the history and physical exam. A rigid fiber optic endoscope of $30^{\circ}$ and $4 \mathrm{~mm}$, Endoview brand was used (Figure 2).

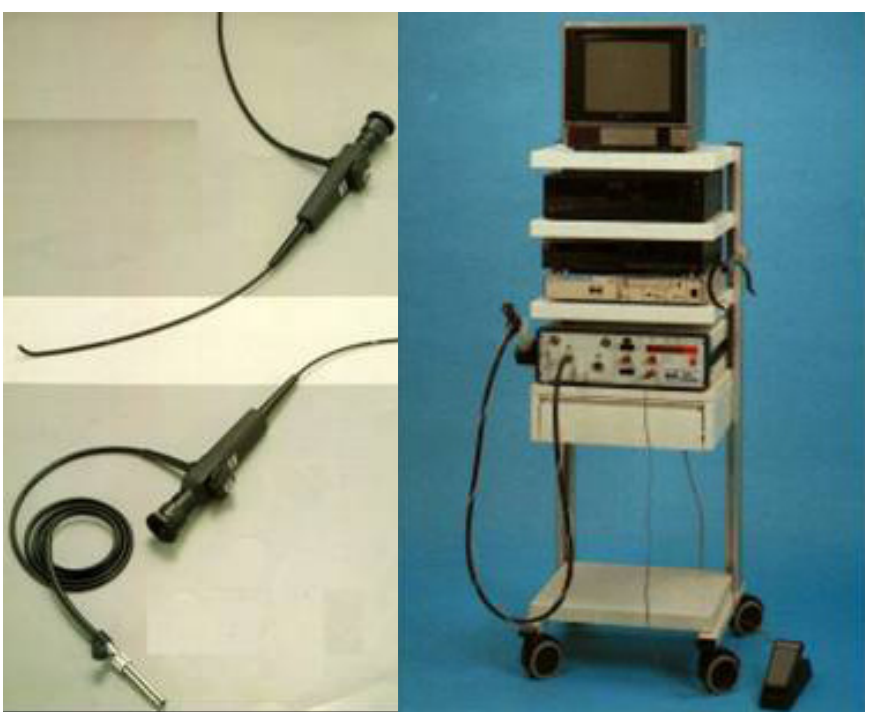

Figure 2. Micro camera and main equipment of the nasofibroscope used.

The reports on the nasofibroscopies were issued by a single otorhinolaryngologist, and the tapes were reviewed and re-evaluated by another professional. Those that were in disagreement with regard to the diagnosis were discarded.

For conception of the numerical result of the Pearson correlation, the parameters identified by Santos ${ }^{10}$ were used.

For the cephalometric evaluation, it was determined that in the cases in which the nasopharyngeal obstruction were greater than or equal to $47 \%$, the patient would be considered affected by adenoid hypertrophy, in accordance with the parameters established by Silva Filo et al. ${ }^{11}$ For the rhinoscopy results (gold standard), the cut-off point was considered $75 \%$, with the result equal to or higher than this value being considered positive for the diagnosis of hypertrophy of the adenoids ${ }^{12}$.

\section{RESULTS}

Comparison between the results obtained in the first and second measure was made by means of the Student's- $t$ test, with a level of significance of 0.05 $(p<0.05)$. For a result of $p$-value equal to 0.366 the measurements used could be considered free of error.

The results revealed a higher mean value of obstruction in the cephalometry exams in comparison with the rhinoscopy test $(42.00 \%$ and $14.50 \%$, respectively). Distribution of the rhinoscopy results pointed towards a small percentage of patients with compromised adenoids, seeing that $75 \%$ or the results were equal to or lower than $26.25 \%$ of obstruction, and in cephalometry fewer than half attained the cut-off point of $47 \%$ obstruction (Table 1). 
Table 1. Summary of descriptive statistics.

\begin{tabular}{|c|c|c|c|c|c|c|}
\hline Exam Variable & Mean & Minimum & Maximum & $\begin{array}{c}25 \% \\
1 \text { st quartile }\end{array}$ & $\begin{array}{l}50 \% \\
\text { Median }\end{array}$ & $\begin{array}{c}75 \% \\
\text { 3rd quartile }\end{array}$ \\
\hline Cephalometry & $42.42 \pm 13.40$ & 0.00 & 66.24 & 36.03 & 40.45 & 51.32 \\
\hline
\end{tabular}

The Pearson correlation found for the cephalometry and rhinoscopy exams was $r=0.498$ for a $p$-value $<$ 0.01 . This result may be considered a moderately positive correlation, in accordance with the Santos ${ }^{10}$ classification.

For the diagnosis of adenoid hypertrophy, rhinoscopy was considered the gold standard. When comparing the number of positive and negative results obtained in the two exams, and taking into consideration the cut-off value of $75 \%$ for the rhinoscopic exam and $47 \%$ for cephalometry, 20 patients were correctly diagnosed ( 1 case positive and 19 negative cases) by means of cephalometry (Table 2).

Table 2. Distribution of patients according to result of exams.

\begin{tabular}{lccc}
\hline \multicolumn{4}{c}{ Rhinoscopy } \\
\hline Cephalometry. & Positive & Negative & Total \\
\hline Positive & 1 & 10 & 11 \\
Negative & 0 & 19 & 19 \\
Total & 1 & 29 & 30 \\
\hline
\end{tabular}

The sensitivity obtained for the cephalometric exam was $100 \%$, and specificity was $65.5 \%$. The positive predictive value of the cephalometric exam was $9.1 \%$ and the negative predictive value was $100 \%$, The exactness of the radiographic exam was $66.6 \%$.

\section{DISCUSSION}

After the results of this research, there is no way of disagreeing with $\mathrm{Chami}^{2}$ and Cohen et al. ${ }^{4}$ that the lateral radiograph is a method of studying the nasopharyngeal region that is easily obtainable and very comfortable for the patient. The exams performed by the otorhinolaryngologists in their daily practice of rhinoscopy, equally do not allow disagreement with Oliveira et al. ${ }^{1}$ that for them, it would allow an absolutely direct observation of the region, providing a notion of the exact size, shape and relationship between the nasal structures and those of the nasopharynx.
In the more objective field, one could observe that the moderately positive correlation found in this study (Pearson's coefficient: 0.498) resembled the values found by Holmberg \& Linder-Aronson ${ }^{3}$, the study of Cohen et al. ${ }^{4}$, (Pearson's coefficient: 0.34) and in Barbosa et al. ${ }^{7}$ who, in their turn, found a correlation of - 0,793 , and in this case, one could consider a strongly positive correlation, in accordance with the scale proposed by Santos ${ }^{10}$.

In the sensitivity and specificity tests the data of this study and those of Barbosa et al. ${ }^{7}$ came close. In this study, the radiographic exam would have a sensitivity of $75 \%$ and specificity of $86.3 \%$, while in the former, the values were $100.00 \%$ and $65.50 \%$ for sensitivity and specificity, respectively.

In disagreement with this research, Gianni Filo et $a^{6}{ }^{6}$, demonstrated that the radiographic exam showed a sensitivity of $0.88 \%$ and a specificity of $0.40 \%$ for the diagnosis of hypertrophy of the inferior turbinate. For the diagnosis of hypertrophy of the middle turbinate, the results found were $1.00 \%$ and $0.20 \%$ for sensitivity and specificity, respectively. This made them conclude that there would be a high rate of false-positive results pointed out by teleradiography. In their interpretations, this fact would be a result of the high bone density of the turbinates, which make them visible in the radiograph, even when they were not really hypertrophic.

Also suggesting insufficiency of radiography for diagnosis of nasopharyngeal obstruction, the study of Wang et al. ${ }^{5}$ was able to correlate the existence of adenoid hypertrophy from a lateral radiograph in $88 \%$ of the cases, when submitted to nasal endoscopy. However, in $26 \%$ of the cases, the radiological exam failed to confirm the adenoidal tissue hypertrophy, when compared with endoscopy.

In spite of disagreement in general, this research is in agreement with Gianni Filo et al. ${ }^{6}$, with regard to the high possibility of teleradiography presenting false-positive results. Seeing that in the majority of studies consulted, which performed tests of sensitivity and specificity, the performance of the specificity factor was shown to be worse, suggesting the possibility of false-positive having occurred in the teleradiographs. 
The development of occlusion is considered the result of interactions between genetic and environmental factors, external and internal factors; here including orofacial function ${ }^{11}$. Making a correct diagnosis is a complex task and demands observation of various aspects, in the same way as the treatment plan must even consider family relations, because permissive parents limit therapeutic options. Therefore, any method that leads to a diagnosis of adenoid hypertrophy must be appreciated within this complex panorama.

The exams in support of the diagnosis are important in order to document, guide the therapy and even to serve as facilitators to explain and make patients

\section{REFERENCES}

1. Oliveira R, Lima W, Souza B. Importância da nasofibroscopia na presença do rx cavum normal para diagnóstico da hiperpasia adenoideana. Rev Bras Otorrinolaringol. 2001;67(4):499-505.

2. Chami FAl. Avaliação nasofibroscópica e radiológica de pacientes com hiperplasia da amígdala faríngea. RBM Rev Bras Med Otorrinolaringol. 1998;5(4):118-25.

3. Holmberg M, Linder-Aronson S. Cephalometric radiographs as a means of evaluating the capacity of the nasal and nasopharyngeal airway. Am J Orthod. 1979;76(5):479-90. doi: 10.1016/0002-9416(79)90252-5

4. Cohen LM, Koltai PJ, Scott JR. Lateral cervical radiographs and adenoid size: do they correlate? Ear Nose Throat J. $1992 ; 71(12): 638-42$

5. Wang DY, Bernheim N, Kaufman L. Assessment of adenoid size in children by fibreoptic examination. Clin Otolaryngol Allied Sci. 1997:22(2):172-7.

6. Ianni Filho D, Raveli DB, Raveli RB, Castro MLL, Gandin Junior LG. A comparison of nasopharyngeal endoscopy and lateral cephalometric radiography in the diagnosis of nasopharyngeal airway obstruction. Am J Orthod Dentofacial Orthop. 2001;120(4):348-52. doi: 10.1067/mod.2001.116824

7. Barbosa MC, Knop LAH, Lessa MM, Araujo TM. Avaliação da radiografia cefalométrica lateral como meio de diagnóstico da hipertrofia de adenoide. Rev Dent Press Ortodon Ortopedi Facial. 2009;14(4):83-91. doi: 10.1590/\$1415-54192009000400009 aware of and responsible with regard to the problem.

\section{CONCLUSION}

The cephalometry obtained from the lateral teleradiograph is a practical method, comfortable for the patient and relatively efficient in the detection of hypertrophy of the adenoids.

\section{Collaborators}

AJ RETCHESKI, NP SILVA, F LEITE and PRA NOUER participated in all the stages of preparation of the article.

8. Moorrees CFA, Kean MR. Natural head position, a basic consideration in the interpretation of cephalometric radiographs. Am J Phys Anthropol. 1958;16(2):213-34. doi: 10.1002/ ajpa.1330160206

9. Rocabado M. Analisis biomecanico craneo cervical através de una teleradiografia lateral. Rev Chilena Ortod. 1984; 1:42-52.

10. Santos C. Estatística descritiva: manual de auto-aprendizagem. Lisboa: Sílabo; 2007.

11. Silva Filho OG, Freitas SF, Cavassan AO. Dimensões da nasofaringe em crianças de sete anos de idade, portadores de oclusão normal: avaliação pela cefalometria. Ortodontia. $1989 ; 22(2): 20-30$

12. Cassano P, Gelardi M, Cassano M, Fiorella ML, Fiorella $R$, Adenoid tissue rhinopharyngeal obstruction grading based on fiberendoscopic findings: a novel approach to therapeutic management. Int J Pediatr Otorhinolaryngol. 2003;67(12):13039. doi: 10.1016/j.ijporl.2003.07.018

13. Adrianopoulos MV, Hanson ML. Tongue-thrust, and stability of overjet correction. Angle Orthod. 1987;57(2):121-35.

Received on: $25 / 5 / 2012$

Final version resubmitted on: 12/3/2013

Approved on: 2/4/2013 
